\title{
SEISMOTECTONICS OF THE SOUTHERN MARMARA REGION, NW TURKEY
}

\author{
Yalçın H. ${ }^{1}$, Kürçer A. ${ }^{2}$, Utkucu M. ${ }^{1}$ and Gülen L. ${ }^{1}$ \\ ${ }^{I}$ Department of Geophysical Engineering, Sakarya University, Serdivan, 54187 Sakarya, Turkey. \\ hdomac@sakarya.edu.tr, mutkucu@sakarya.edu.tr,lgulen@sakarya.edu.tr \\ ${ }^{2}$ Department of Geological Research, General Directorate of Mineral Research and Exploration, \\ 06800 Ankara,Turkey,akin.kurcer@mta.gov.tr
}

\begin{abstract}
The Southern Marmara Region is an active deformation area, which is a transition zone between the strike-slip tectonics manifested by the North Anatolian Fault System and the $\mathrm{N}$-S extensional regime of the Aegean Region.

We have reviewed tectonic and geological structure of the region, based on seismological studies. We have obtained a total of 37 earthquake moment tensor solutions between 1953 and 2015. In addition, stress tensor analysis has been carried out using 37 earthquake moment tensor solutions. Also long term seismicity were investigated and $a, b, M c$ values were calculated and mapped. Moment tensor solutions indicate that the source of these earthquakes are mostly NE-trending dextral strike-slip faults and some of them are E-W trending dip-slip normal faults. The stress tensor analysis shows that the direction of the regional compressive stress is NW-SE.

The temporal and spatial distrubution of the large earthquakes (1944, 1953, 1964) indicate that the ruptures unilaterally propagate from $S W$ to $N E$. The 1855 earthquake had been occurred to the east of Manyas Lake. The elapsed time (160 year) and regional stress transfer suggest that the segments to the east of Manyas Lake form a probable seismic gap and this area has a high earthquake risk.

Keywords: Moment Tensor Solution, Stress Tensor Analysis, $b$ value, North Anatolian Fault, Southern Marmara Region, Aegean Region.
\end{abstract}

\section{Introduction}

The active deformation in the eastern Mediterranean region is closely associated with the Aegean and Cyprean subduction zones and the continental collision that is taking place between the AfricanArabian and the Eurasian plates. As a result, active tectonics of the eastern Mediterranean region is mainly controlled by the dextral North Anatolian Fault System (NAFS) and the sinistral East Anatolian Fault System (EAFS), The Dead Sea Fault Zone (DSFZ) and the Aegean and Cyprean Subduction Zones.

The NAFS is a major active dextral strike-slip fault system in the eastern Mediterranean region. It extends from the Karlova triple junction in eastern Turkey to the Gulf of Saros in the North Aegean Sea for an approximately $1200 \mathrm{~km}$ (Barka and Gülen, 1988 and Şengör et al., 2004) (Figure 1). The NAFS continues across the northern Aegean Sea, and it crosses central mainland Greece as a broad shear zone (termed the Gracian Shear Zone by Şengör, 1979) and it eventually links up with the Aegean Arc (Dewey and Şengör, 1979; Le Pichon et al., 1993; McKenzie and Jackson, 1983 and Şengör et al., 2004). The NAFS bifurcates into three strands just to the east of Sakarya, around the 
Mudurnu valley, forming a horse-tail structure (Barka and Gülen, 1988 and Barka, 1992) (Figure 1). The northern strand starts from the south-east of Sapanca Lake and it passes through the Marmara Sea, Gulf of Saros and the North Aegean Trough (Lyberis, 1984 and Kürçer et al., 2015). The central strand follows the path through Geyve basin, Pamukova, South of İznik Lake, southern coast of Marmara Sea and Bandırma, where it makes a restraining bend and continues south-west in the Biga Peninsula (Kürçer et al., 2015). The central strand of NAFS consists of several dextral strike-slip fault segments in the Biga Peninsula. The southern strand of NAFS consists of the Bursa Fault, the Uluabat Fault, the Manyas Fault, the Yenice Gönen Fault, the Evciler Fault and the Edremit Fault in Biga Peninsula and it extends towards the Skyros Basin in the Aegean Sea (Figure 1). The deformation of the Southern Marmara Region is mainly controlled by the middle and southern strands of the NAFS and the Aegean Extensional Regime. The seismotectonic characteristics of the Southern Marmara Region and its vicinity have been studied by several authors (see Üçer et al., 1997; Nalbant et al., 1998; Gürbüz et al., 2000; Gürer et al., 2003 and 2006 and Kürçer et al., 2015). Neotectonic and paleoseismological studies on several segments of the middle and southern strand of the NAFS produced new data about the kinematic characteristics and the time record of major earthquakes (Kürçer et al., 2008). The GPS measurements show that relative displacement of Anatolia with respect to Eurasia is mainly accomodated by the northern strand of the NAFS (Straub and Kahle, 1994, 1995; Barka and Reilinger, 1997; Meade et al., 2002; Kreemer et al., 2004 and Reilinger et al., 2006). The two other strands of the NAFS are less active with respect to the northern strand. Meade et al. (2002) suggest $6.8 \pm 2.3 \mathrm{~mm} / \mathrm{yr}$ and similarly, Kreemer et al. (2004) suggest 7 $\mathrm{mm} / \mathrm{yr}$ strike-slip rates for these middle and southern strands of the NAFZ. Many destructive and moderate earthquakes have occurred in the southern Marmara region during both historical and instrumental periods. Some of these are the October 6, 1944 Gulf of Edremit - Ayvacik earthquake (Ms=6.8; Ambraseys, 1988), the March 18, 1953 Yenice-Gönen earthquake (Ms=7.2; McKenzie, 1972), the October 6, 1964 Manyas earthquake (Ms=6.9; Taymaz et al., 1991). Many destructive historical earthquakes had occured in this area such as AD. 123, 160, 368, 1855 (Ambraseys, 2002), AD. 1737 and 1850 (Ambraseys and Jackson, 2000), AD. 155, 543, 1323 (Ambraseys and Finkel, 1991).

This study is mainly concerned with the interactions between earthquakes that occured in the region and temporal and spatial distribution of these events. The aim of this paper is to better understand the geometric and kinematic features of the faults in the Southern Marmara Region. The current state of stress of the regional crust has been investigated and the results are discussed in the context of regional tectonic setting and seismic hazard assessment.

\section{Moment Tensor Solution, Stress Tensor Analysis and $b$ value analysis}

In this study a regional seismic source model has been prepared using an updated active fault database, instrumental and historical earthquake database for the study area. The instrumental earthquake near field wave forms were obtained from the Kandilli Observatory and Earthquake Research Institute Regional Earthquake-Tsunami Monitoring Center (KOERI-RETMC). Firstly, source parameters of 30 events that have magnitudes $\mathrm{Mw} \geq 3.3$ have been modelled by seismic moment tensor inversion developed by Sokos and Zahradnik (2006) algorithm (Figure 2). Secondly, stress tensor inversions have been carried out using the Micheal (1987) method. The results of the moment tensor solutions for earthquakes with moment magnitude greater than $\mathrm{Mw}>1.9$ (Table 1) were inverted to obtain stress tensors and they were mapped (Figure 3). Orientation of the $\sigma 1, \sigma 2$, and $\sigma 3$ were computed and the principal stress axes are projected onto a lower hemisphere Wulff net. The shape factor (R) was calculated by using the focal mechanism solutions for the seismogenic zone.

The results of regional stress tensor analysis for the shape and orientation of the stress tensors calculated from the obtained 37 fault plane solutions (Figure 2). The principal directions are projected onto a lower hemisphere Wulff net. The white rectangle, green triangles and purple circles indicate the azimuths and plunges of the maximum compression axis $\sigma 1$, the intermediate stress axis $\sigma 2$ and the minimum stress axis $\sigma 3$. 


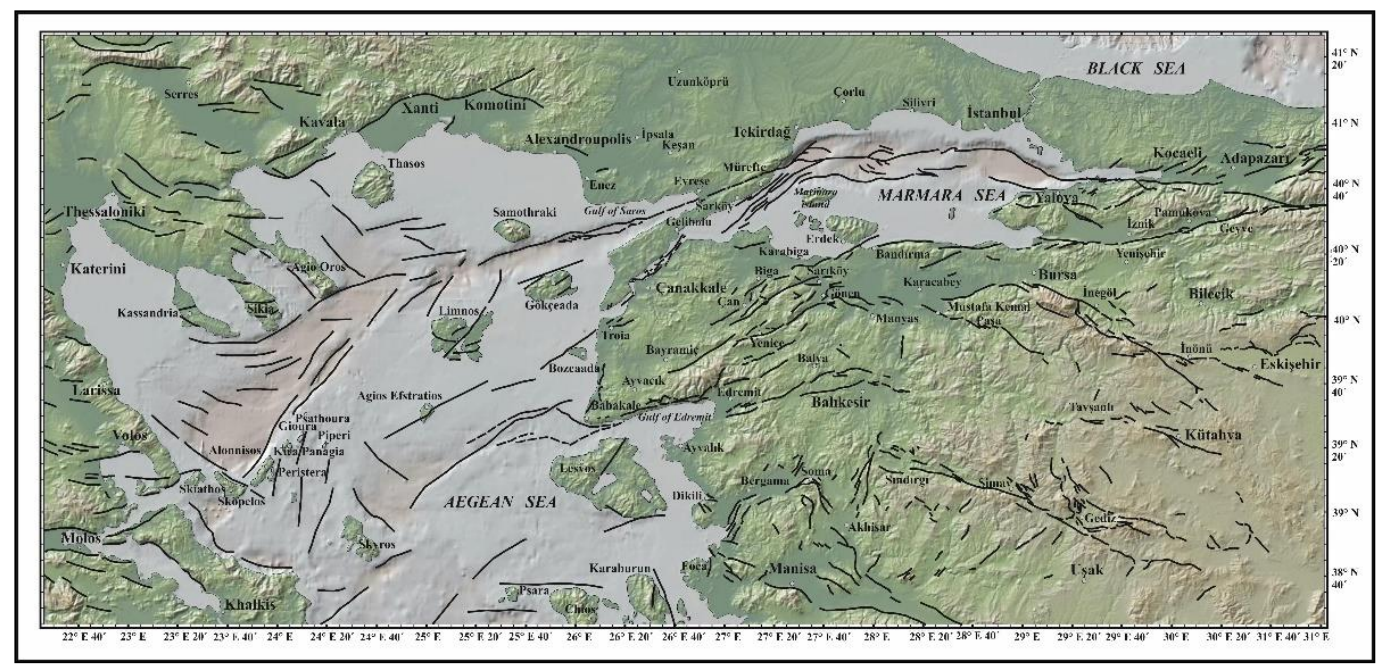

Figure 1 - Active faults in the western Turkey, northern Aegean Sea and northern Greece (active faults were compiled from the following references; in mainland Turkey: Emre et al.

(2013) and the references included therein; Troy area: Kürçer et al. (2012); South-west

Marmara Sea: Yaltirak (2002); Çanakkale Strait: Gökaşan et al. (2008); active faults at the western part of Gulf of Edremit and its vicinity: Yaltirak et al. (2012); North-eastern Greece:

Pavlides et al. (2007); Agios Efstratios fault: Chatzipetros et al. (2012); active faults near Bozcaada: Kürçer et al. (2015).

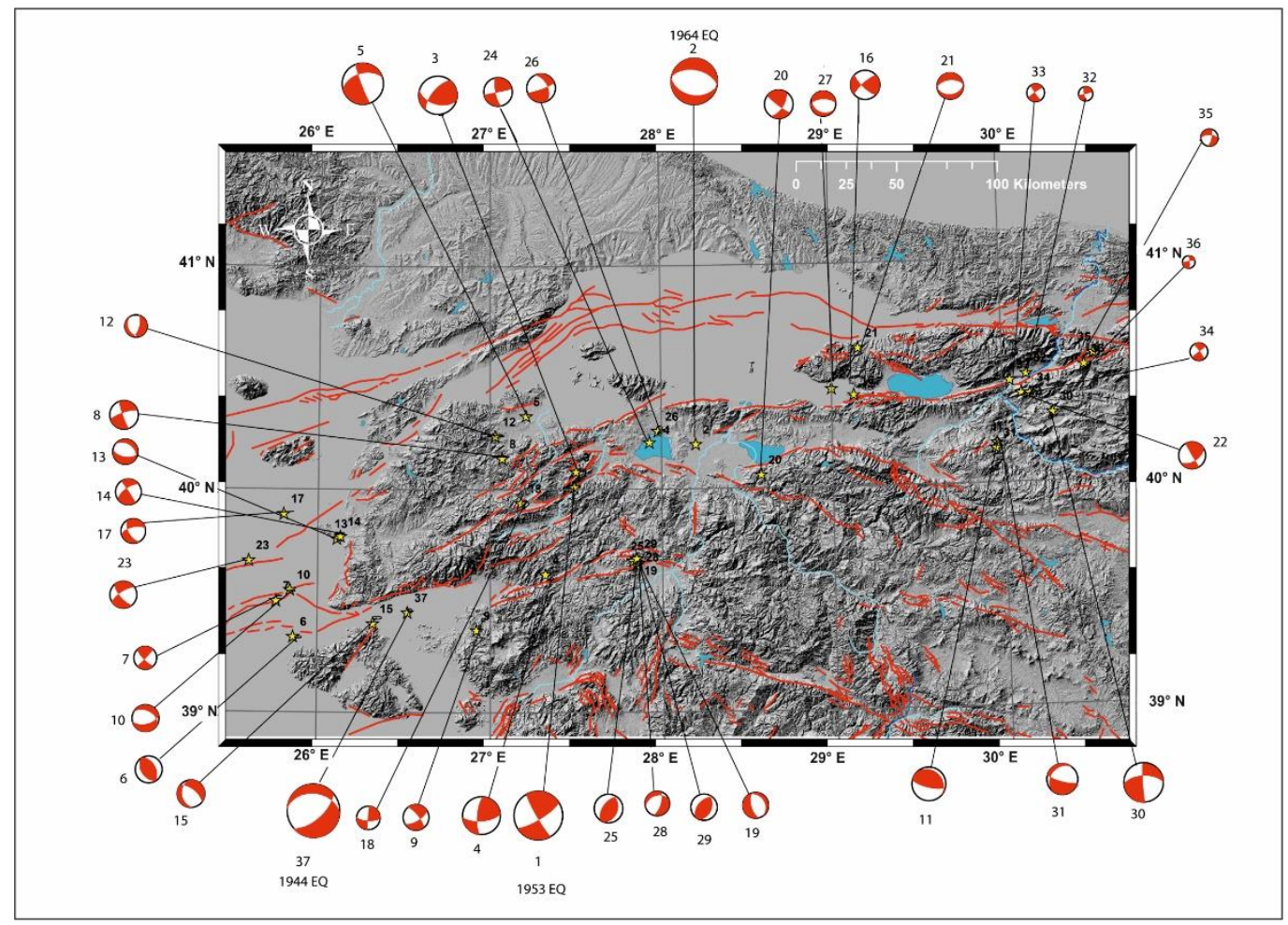

Figure 2 - Focal mechanisms and MT solutions compiled and obtained respectively in the study for the region. The numbers in the map and near the mechanisms indicate earthquake numbers in Table 1 which also contain source parameters. 
The best fit was attained for Phi $=0.75+/-0.12964$ that indicates that the stress regime is strike slip with azimuth and plunge pair of $\left(-72.5^{\circ}, 19.9^{\circ}\right)$ for $\sigma 1,\left(142.3^{\circ}, 66.2^{\circ}\right)$ for $\sigma 2$ and $\left(22.1^{\circ}, 12.5^{\circ}\right)$ for $\sigma 3$, respectively (Figure 3a).The stress tensor analysis of studied earthquakes in the region indicates that the region has predominantly strike-slip faulting with a minor normal component (Figure 3). These results indicate the presence of a transtensional tectonic regime in the southern Marmara region.

Thirdly, an instrumental earthquake catalog was prepared for the seismogenic zone using the seismic database of KOERI-RETMC. Aftershocks, foreshocks and earthquake swarms are removed using the declustering algorithm of Reasenberg (1985). As a result of declustering a total of 1357 events that form 402 clusters were removed from the dataset. Gutenberg and Richter (1944) parameters (a and $b$ values) were calculated for the seismic source. $b$ value is a constant parameter which has been shown to be inversely related to the stress in the crust (Wiemer and Wyss, 1997), and the a value is a function of earthquake activity rate of the crust, size of the region, and observation time (Kalafat et al., 2013). Especially, the time distribution histogram of the catalog indicates that the seismic catalog is complete for which magnitude $\mathrm{Mc}=2.9$ since 1983 for the seismogenic zone. Therefore, the KOERI catalog was re-analysed for the period between 1983-2015. Based on the maximum likelihood solution; we obtained $b=1.29+/-0.1$ and $a=7.3$.

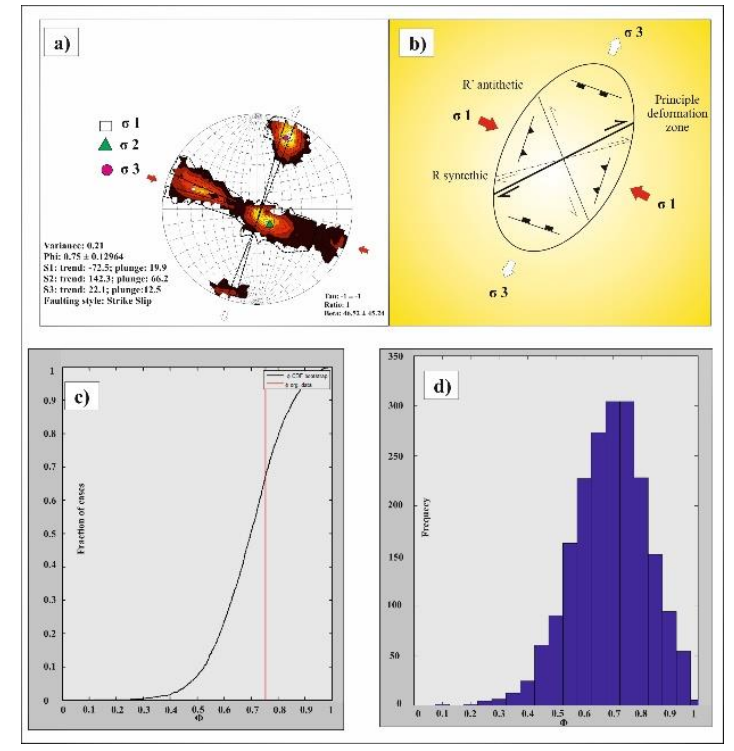

Figure 3 - a) The result of regional stress tensor analysis for the shape and orientation of the stress tensor calculated from compiled and the obtained 37 fault plane solutions given in Table 1 a) The white rectangle, green triangles and purple circles indicate the azimuths and plunges of the maximum compression axis $\sigma 1$, the minimum stress axis $\sigma 3$ and the intermediate stress axis $\sigma 2$. The best fit was attained for $P h i=0.75+/-0.12964$ that indicates that the stress regime is strike slip with azimuth and plunge pair of $\left(-72.5^{\circ}, 19.9^{\circ}\right)$ for $\sigma 1,\left(142.3^{\circ}, 66.2^{\circ}\right)$ for $\sigma 2$ and $\left(22.1^{\circ}, \mathbf{1 2 . 5}^{\circ}\right)$ for $\sigma 3$, respectively b) Strain ellipsoid for a dextral strike-slip fault (Principle deformation zone), the positions of the sigma 1 and sigma 3 principal axes of stress, and the $R$ and $R$ ' orientations c) The plot of stress ratio relative to fraction cases $d$ ) The histogram of $R$ -

value. Note that the inversion result indicates a strike-slip regime with minor normal component that has a relative stress magnitude of between 0.5 and 1.

The variation of $b$ values has been mapped. $a-b$ values and completeness magnitude have been computed using the maximum likelihood method (Aki, 1965) and Wiemer (2001) algorithm. Based on the maximum likelihood solution; The variance of $b$ value changes in the range of $0.5-1.40$ within the seismogenic zone in the southern Marmara (Figure 4). 
Table 1- Source parameters of the earthquakes used in the study (References: 1- McKenzie, 1972; 2- Taymaz et al., 1991; 3- Papadopoulos et al., 1986; 4- Harvard Univ., 1998; 5- This study; 6- Altuncu Poyraz et al., 2015; 7-Altınok et al., 2012).

\begin{tabular}{|c|c|c|c|c|c|c|c|c|c|c|c|}
\hline No & Lon & Lat & Year & $\mathbf{M}$ & Day & Mw & Depth & Str. & Dip & Rake & Ref \\
\hline 1 & 27.49 & 40.01 & 1953 & 3 & 18 & 7.2 & 40 & 59 & 76 & 174 & 1 \\
\hline 2 & 28.20 & 40.20 & 1964 & 10 & 6 & 6.9 & 14 & 100 & 40 & -90 & 2 \\
\hline 3 & 27.50 & 40.08 & 1969 & 3 & 3 & 5.7 & 4 & 219 & 65 & 45 & 1 \\
\hline 4 & 27.32 & 39.62 & 1971 & 2 & 23 & 5.6 & 10 & 86 & 66 & 160 & 3 \\
\hline 5 & 27.21 & 40.33 & 1983 & 7 & 5 & 6.1 & 15 & 254 & 49 & -173 & 4 \\
\hline 6 & 25.86 & 39.34 & 2006 & 4 & 24 & 4.0 & 6 & 146 & 44 & 86 & 5 \\
\hline 7 & 25.76 & 39.50 & 2007 & 1 & 8 & 3.4 & 16 & 44 & 87 & 166 & 5 \\
\hline 8 & 27.07 & 40.14 & 2014 & 12 & 16 & 4.2 & 2 & 252 & 77 & -173 & 5 \\
\hline 9 & 26.92 & 39.37 & 2005 & 8 & 3 & 3.8 & 8 & 59 & 65 & -162 & 5 \\
\hline 10 & 25.84 & 39.55 & 2007 & 1 & 8 & 4.0 & 4 & 77 & 55 & -116 & 5 \\
\hline 11 & 29.96 & 40.18 & 2011 & 7 & 11 & 5.0 & 5 & 103 & 73 & 80 & 5 \\
\hline 12 & 27.03 & 40.24 & 2012 & 1 & 12 & 3.3 & 15 & 154 & 31 & -126 & 5 \\
\hline 13 & 26.11 & 39.78 & 2014 & 1 & 7 & 3.7 & 8 & 304 & 36 & -70 & 5 \\
\hline 14 & 26.13 & 39.79 & 2014 & 1 & 13 & 3.8 & 10 & 235 & 65 & 177 & 5 \\
\hline 15 & 26.32 & 39.40 & 2015 & 1 & 19 & 4.1 & 33 & 308 & 63 & -114 & 5 \\
\hline 16 & 29.13 & 40.41 & 2015 & 5 & 11 & 4.3 & 5 & 134 & 74 & 166 & 5 \\
\hline 17 & 25.80 & 39.89 & 2009 & 6 & 23 & 3.6 & 24 & 257 & 65 & -144 & 5 \\
\hline 18 & 27.18 & 39.94 & 2009 & 3 & 29 & 3.5 & 4 & 94 & 68 & 178 & 5 \\
\hline 19 & 27.85 & 39.66 & 2015 & 3 & 18 & 3.8 & 16 & 327 & 28 & -106 & 5 \\
\hline 20 & 28.58 & 40.06 & 2015 & 1 & 23 & 4.2 & 12 & 127 & 83 & 29 & 5 \\
\hline 21 & 29.16 & 40.62 & 2014 & 8 & 3 & 3.9 & 5 & 82 & 36 & -92 & 5 \\
\hline 22 & 30.11 & 40.40 & 2014 & 10 & 22 & 4.0 & 5 & 59 & 52 & 179 & 5 \\
\hline 23 & 25.60 & 39.68 & 2013 & 1 & 9 & 4.0 & 4 & 237 & 70 & -159 & 5 \\
\hline 24 & 27.93 & 40.21 & 2014 & 7 & 3 & 4.2 & 12 & 78 & 88 & 166 & 5 \\
\hline 25 & 27.83 & 39.68 & 2015 & 7 & 2 & 4.2 & 7 & 215 & 57 & 100 & 5 \\
\hline 26 & 27.98 & 40.26 & 2006 & 10 & 20 & 4.2 & 5 & 70 & 82 & -141 & 5 \\
\hline 27 & 29.00 & 40.44 & 2006 & 10 & 25 & 3.7 & 11 & 268 & 62 & -104 & 5 \\
\hline 28 & 27.86 & 39.67 & 2015 & 6 & 30 & 3.6 & 17 & 250 & 37 & -43 & 5 \\
\hline 29 & 27.85 & 39.69 & 2015 & 7 & 2 & 3.9 & 5 & 221 & 50 & 103 & 5 \\
\hline 30 & 30.29 & 40.31 & 1999 & 9 & 13 & 5.8 & 15 & 176 & 86 & -31 & 4 \\
\hline 31 & 29.95 & 40.15 & 2011 & 7 & 11 & 4.6 & 6 & 105 & 77 & -66 & 6 \\
\hline 32 & 30.14 & 40.48 & 2012 & 6 & 28 & 2.1 & 6.8 & 77 & 88 & 163 & 6 \\
\hline 33 & 30.04 & 40.45 & 2012 & 7 & 10 & 2.6 & 9.4 & 236 & 83 & 175 & 6 \\
\hline 34 & 30.16 & 40.39 & 2013 & 1 & 23 & 2.6 & 1.8 & 53 & 89 & -172 & 6 \\
\hline 35 & 30.54 & 40.57 & 2013 & 3 & 7 & 2.5 & 5.2 & 11 & 68 & -151 & 6 \\
\hline 36 & 30.48 & 40.52 & 2013 & 4 & 13 & 1.9 & 6.9 & 354 & 79 & 11 & 6 \\
\hline 37 & 39.45 & 26.52 & 1944 & 10 & 6 & 6.7 & $*$ & * & * & $*$ & 7 \\
\hline
\end{tabular}




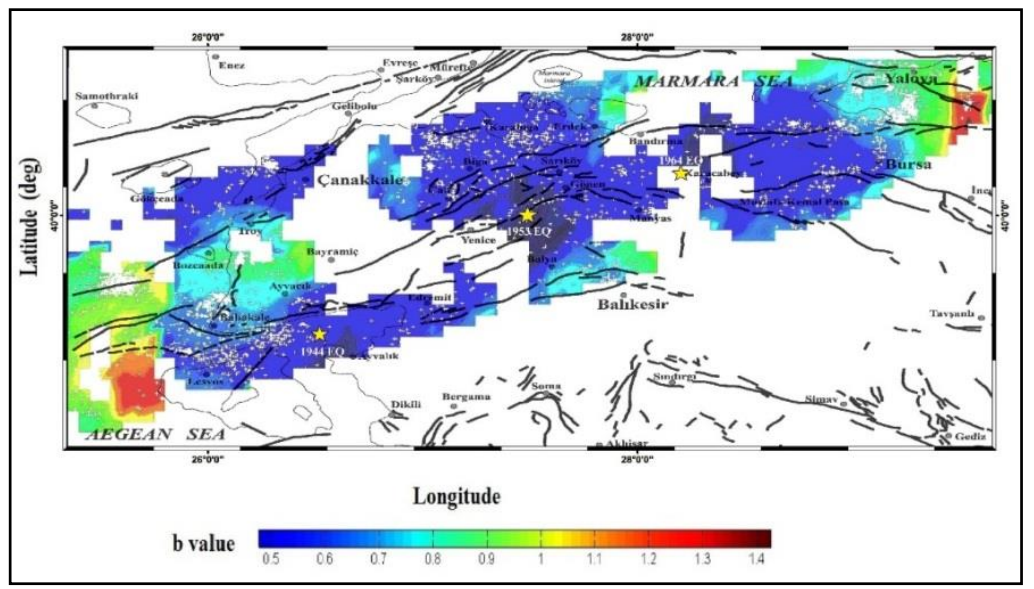

Figure 4 - Map view of spatial distribution of $b$ values using the best combination maximum likelihood method for the time period between 1905-2015 instrumental catalog. The number of earthquakes per sample is 50, the nodal separation is $0.025^{\circ}$, and the radius of the cylindrical sample volumes is $R \geq 20 \mathbf{~ k m}$.

\section{Discussion and Conclusion}

In this study, source parameters of the southern Marmara region earthquakes are investigated using the seismic moment tensor method. The sources of southern Marmara Region earthquakes are mainly NE-SW trending dextral strike-slip faults and to a lesser extend E-W normal faults based on the earthquake moment tensor solutions and spatial distribution of the earthquake epicenters. The stress tensor inversions are analysed using focal mechanism solutions and fault groups using a total of 37 earthquakes (Table 1 and Figure 3 ). We have obtained the three principle stresses ( $\sigma 1, \sigma 2$ and $\sigma 3)$ and their relative size and uniformity of stress field variations for the all events in the studied region. Stress tensor results indicate a strike-slip tectonic regime with minor normal component in the southern Marmara region. The 1944 Gulf of Edremit - Ayvacık and 1964 Manyas earthquakes were occurred on oblique faults that have major normal and minor right lateral strike slip component. The $b$ value varies in the range of 0.5 to 1.4 for the time period between 1905-2015 for the seismic source zone. Although the segments in the southwestern and northeastern tips of the study area have high $\mathrm{b}$ values around 1.1- 1.4, the central segments have very low $\mathrm{b}$ values around $0.5-0.8$ (Figure 4 ). The highest $b$ values were observed on the offshore fault segments (near the Lesvos island), so we may conclude that a major energy release had occurred during the devastating 1944 Gulf of Edremit - Ayvacik earthquake. Apparently, after the October 6, 1944 Gulf of Edremit-Ayvacik earthquake $(\mathrm{Mw}=6.7)$, stress had been transferred to the 1953 earthquake segment in the NW. Similarly, after the March 18, 1953 Yenice - Gönen earthquake (Mw=7.2), stress had been transferred to the October 6, 1964 Manyas earthquake $(\mathrm{Mw}=6.9)$ earthquake segment to the east. These earthquakes and recent earthquakes to the east of Manyas Lake region indicate that there is a big earthquake hazard potential. The spatial and temporal distribution of these earthquakes indicates that the surface ruptures unilaterally propogate from SW to NE. The 1855 earthquake had been occurred to the east of Manyas Lake. The elapsed time of 160 years and the regional stress transfer point out that the segments at the east of Manyas Lake may represent a probable seismic gap and a potential earthquake hazard for this region.

\section{Acknowledgments}

We thank the staff of the Kandilli Observatory and Earthquake Research Institute Regional Earthquake-Tsunami Monitoring Center (KOERI-RETMC) for the broad-band data used in this study. We thank anonymous reviewers for their constructive critisms which improved the 
manuscript. This research was funded by Research Fund of the Sakarya University (Project numbers: 2012-01-14-005 and 2012-01-14-006). The maps were prepared using the Generic Mapping Tools (GMT) software (Wessel and Smith, 1991).

\section{References}

Aki, K., 1965. Maximum Likelihood Estimate of $\mathrm{b}$ in the formula $\log \mathrm{N}=\mathrm{a}-\mathrm{bM}$ and its confidence limits, Bull. Earthquake. Res. Inst. Tokyo Univ., 43, 237-239.

Altinok. Y., Alpar. B., Yaltirak. C., Pinar. A. and Özer. N., 2012. The earthquakes and related tsunamis of October 6, 1944 and March 7, 1867, NE Aegean Sea, Nat. Hazards, 60, 3-25.

Altuncu Poyraz, S., Teoman, M.U., Türkelli, N., Kahraman, M., Cambaz, D., Mutlu, A., Rost, S., Houseman, G.A., Thompson, D.A., Cornwell, D., Utkucu, M. and Gülen, L, 2015. New constraints on micro-seismicity and stress state in the western part of the North Anatolian Fault Zone: Observations from a dense seismic array, Tectonophysics, 656, 190-201.

Ambraseys, N.N., 1988. Engineering Seismology, J Earthq. Eng. Struct. Dyn., 17, 1-105.

Ambraseys, N.N., 2002. The seismic activity of the Marmara Sea region over the last 2000 years. Bulletin of the Seismological Society of America, 92(1), 1-18.

Ambraseys, N.N. and Finkel, CF., 1991. Long-term seismicity of Istanbul and of the Marmara Sea region, Terra Nova, 3, 527-39.

Ambraseys, N.N. and Jackson, J., 2000. Seismicity of the Sea of Marmara (Turkey) since 1500, Geophys. J. Int., 141, F1-F6.

Barka, A.A., 1992. The North Anatolian Fault zone, Annales Tecton., 6, 164-195.

Barka, A.A. and Reilinger, R., 1997. Active tectonics of the Eastern Mediterranean region: deduced form GPS, neotectonic and seismic data, Annali Di Geofisica, XL, 587-610.

Barka, A. and Gülen, L., 1988. New constrains on age and total offset on the North Anatolian Fault Zone: Implications for tectonics of the Estern Mediterranean Region, Metu Journal of Pure and Applied Sciences, 21(1-3), 39-63.

Chatzipetros, A., Kiratzi, A., Sboras, S., Zouros, N. and Pavlides, S., 2012. Active faulting in the Northeastern Aegean Sea Islands, Tectonophysics, http://dx.doi.org/ 10.1016/j.tecto.2012.11.026.

Dewey, J.F and Şengör, A.M.C., 1979. Aegean and surrounding regions: complex multiplate and continuum tectonics in a convergent zone, Geol. Soc. Am. Bull. 90, 84-92.

Emre, Ö., Duman, T.Y., Özalp, S., Elmacı, H., Olgun, Ş. and Şaroğlu, Ş., 2013. Active Fault Map of Turkey with Explanatory Text, General Directorate of Mineral Research and Exploration, Special Publication Series-30, Ankara, Turkey.

Gökaşan, E., Ergin, M., Özyalvaç, M., Sur, H.E., Tur, H., Görüm, T., Ustaomer, T., Batuk, F.G., Alp, H., Birkan, H., Türker, A., Gezgin, E. and Özturan, M., 2008. Factors controlling the morphological evolution of the Çanakkale Strait (Dardanelles, Turkey), Geo-Mar Lett., 28, 107-129, doi: 10.1007/s00367-007-0094-y.

Gutenberg, R. and Richter, C.F., 1944. Frequency of earthquakes in California, Bulletin of the Seismological Society of America, 34, 185-188.

Gürbüz, C., Aktar, M. and Eyidoğan, H., 2000. The seismotectonics of the Marmara region (Turkey): results from a microseismic experiment, Tectonophysics, 316, 1-17.

Gürer, Ö.F., Kaymakçı, N., Çakır, S. and Özburan, M., 2003. Neotectonics of the southeast Marmara region, NW Anatolia, Turkey, Journal of Asian Earth Sciences, 21, 1041-51.

Gürer, Ö.F., Sangu, E. and Özburan, M., 2006. Neotectonics of the SW Marmara region, NW Anatolia, Turkey, Geol. Mag., 143(2), 229-241.

Kalafat, D., Kekovalı, K., Akkoyunlu, F. and Öğütçü, Z., 2013. Source mechanism and stress analysis of 23 October 2011 Van Earthquake (Mw=7.1) and aftershocks, J. Seismol., doi: 10.1007/б10950-013-9413-0.

Kreemer, C., Chamot-Roke, N. and Le Pichon, X., 2004. Constraints on the evolution and vertical coherency of deformation in the North Aegean from a comparison of geodetic, geologic and seismologic data, Earth Planet. Sci. Lett., 225, 329-346. 
Kürçer, A., Chatzipetros, A., Tutkun, S.Z., Pavlides, S., Ateş, Ö. and Valkaniotis, S., 2008. The Yenice-Gönen Active fault (NW Turkey): Active tectonics and palaeoseismology, Tectonophysics, 453, 263-275.

Kürçer, A., Chatzipetros, A., Tutkun, S.Z., Pavlides, S., Özden, S., Syrides, G., Vouvalides, K., Ulugergerli, E., Ateş, Ö. and Ekinci, Y.L., 2012. An Assessment of the Earthquakes of Ancient Troy, NW Anatolia, Turkey, Tectonics - Recent Advances, Sharkov, E., ed., ISBN: 978-953-51-0675-3, InTech, Available from: http://www.intechopen.com/books/tectonicsrecent-advances/an-assessment-of-the-earthquakes-of-ancient-troy-nw-anatolia-turkey.

Kürçer, A., Yalçın, H., Gülen, L. and Kalafat, D., 2015. 8 January 2013 Mw = 5.7 North Aegean Sea earthquake and its seismotectonic significance, Geodinamica Acta, 27, 2-3, 175-188, doi: 10.1080/09853111.2014.957503.

Le Pichon, X, Chamot-Rooke, N., Huchon, P. and Luxey, P., 1993. Implications des nouvelles mesures de géodésie spatiale en Grèce et en Turquie sur l'extrusion latérale de l'Anatolie et de l'Egée, C.R. Acad. Sci. Ser., II, 316, 983-90.

Lyberis, N., 1984. Tectonic evolution of the North Aegean Trough. In: The Geological Evolution of Eastern Mediterranean, Dixen, J.G. and Robertson, A.H.F., eds., Spack. Publ. Geol. Sock., London, 711-725.

McKenzie, D.P. and Jackson, J., 1983. The relationship between strain rates, crustal thickening, palaeomagnetism, finite strain and fault moments within a deforming zone, Earth Planet. Sci. Lett., 65, 182-202.

McKenzie, D.P., 1972. Active tectonics of the Mediterranean region, Geophys. J. R. Astron. Soc., 30(2), 109-185.

Meade, B., Hager, B. and Reilinger, R., 2002. Estimates of seismic potential in the Marmara region from block models of secular deformation constrained by GPS measurements, Bull. Seismol. Soc. Am., 92(1), 208-215.

Micheal, A.J., 1987. Use of focal mechanisms to determine stress: a control study, J. Geophys. Res., 92, 357-368.

Nalbant, S.S., Hubert, A. and King, G.C.P., 1998. Stress coupling between earthquakes in northwest Turkey and the North Aegean Sea, J. Geophys. Res., 103, 24469-24486.

Papadopoulos, G.A., Kondopoulou, D.P., Levantakis, G.A. and Pavlides, S.B., 1986. Seismotectonics of the Aegean Region, Tectonophysics, 1424, 67-84.

Pavlides, S., Valkaniotis, S. and Chatzipetros, C., 2007. Seismically capable faults in Greece and their using seismic hazard assessment, 4th International Conference on Earthquake Geotechnical Engnering June, 25-28, Paper No. 1609.

Reilinger, R., McClusky, S., Vernant, P., Lawrence, S., Ergintav, S., Cakmak, R., Ozener, H., Kadırov, F., Guliev, I., Stepanyan, R., Nadarıya, M., Hahubia, G., Mahmoud, S., Sakr, K., ArRajehı, A., Paradissis, D., Al-Aydrus, A., Prilepin, M., Guseva, T., Evren, E., Dmitrotsa, A., Filikov,S.V., Gomez, F., Al-Ghazzi, R. and Karam, G., 2006. GPS constraints on continental deformation in the Africa-Arabia-Eurasia continental collision zone and implications for the dynamics of plate inte ractions, Journal of Geophysical Research, 111, B05411.

Reasenberg, P., 1985. Second-order moment of central California seismicity: 1969-1982, J. Geophysics. Res., 90, 5479-5495.

Sokos, E. and Zahradnik, J., 2006. A Matlab GUI for use with ISOLA Fortran codes (User's Guide), Ver. 2.5. June 2006, 34 pp.

Straub, C. and Kahle, H.G., 1994. Global positioning System (GPS) estimates of crustal deformation in the Sea of Marmara region, Northwestern Anatolia, Earth Planet Sci. Lett., 121, 495-502.

Straub, C. and Kahle, H.G., 1995. Active crustal Deformation in the Sea of Marmara region, NW Anatolia, inferred from GPS measurements, Geophys. Res. Lett., 2 2, 2533-2536.

Straub, C.S., 1996. Recent crustal deformation and strain accumulation in the Marmara Sea region, N.W. Anatolia, inferred from GPS measurements, unpub. Ph.D. dissertation, Swiss Federal Institute of Technology at Zurich, 122 pp., plus appendices. 
Şengör, A.M.C., Tüysüz, O., İmren, C., Sakınç, M., Eyidoğan, H., Görür, N., Le Pichon, X. and Rangin, C., 2004. The North Anatolian Fault: A New Look. Annu. Rev. Earth Planet. Sci., 33, 1-77, doi: 10.1146/annure.earth.32.101802.120415, 1-77.

Şengör, AMC., 1979. The North Anatolian Transform Fault: its age, offset and tectonic significance. J. Geol. Soc. London, 136, 269-82.

Taymaz, T., Jackson, J. and McKenzie, D.P., 1991. Active tectonics of the North and Central Aegean Sea, Geophy. J. Inter., 106, 433-490.

Üçer, B., Eyidogan, H., Gurbuz, C., Barka, A. and Serif, B., 1997. Seismic investigations of Marmara region in Active Tectonics of Northwest Anatolia. In: Schindler, C. and Pfister, M., eds., The Marmara Poly-project, Hochschulverlag AG ander ETH, Zurich, 55-87.

Yalttrak, C., 2002. Tectonic evolution of the Marmara Sea and its surroundings, Marine Geology, 190(20012), 493-529.

Yaltırak, C., İşler, E.B., Aksu, A.E. and Hiscot, R.N., 2012. Evolution of the Bababurnu Basin and shelf of the Biga Peninsula: Western extension of the middle strand of the North Anatolian Fault Zone, Northeast Aegean Sea, Turkey, Journal of Asian Earth Sciences, 57, 103-119.

Wiemer, S. and Wyss, M., 1997. Mapping the frequency-magnitude distribution in asperities: an improved technique to calculate recurrence times, J. Geophys. Res., 102, 15,115-15,128.

Wiemer, S.A., 2001. Software package to analyse seismicity: ZMAP, Seis. Res. Lett., 72(2), 374-383.

Wessel, P. and Smith, W.H.F., 1991. Free software helps map and display data. EOS Transactions $A G U, 72,441-461$. 